\title{
Evaluation of Chrysoperla Carnea for Population Management of Jassid Amrasca Devastans in B.t. Cotton Crop
}

\author{
Abdul Samad Soomro ${ }^{*} \quad$ Shabana Naz Mazari ${ }^{2} \quad$ Tufail Ahmed Wagan ${ }^{3} \quad$ Muhammad Haroon Hulio ${ }^{2}$ \\ 1.Rice Research Institute, Dokri, Pakistan \\ 2.Department of Entomology, SAU-SZABAC, Dokri, Pakistan \\ 3.Department of Plant Protection, SAU-SZABAC, Dokri, Pakistan
}

\begin{abstract}
Evaluation of Chrysoperla carnea [Steph.], for the management of jassid in B.T. Cotton crop was carried out in Randomized Complete Block Design (RCBD) with 4 replications. There were four treatments: T1=Chrysoperla carnea (natural enemy), T2= Confidor (insecticide), T3=B.T. control and T4= NIAB-78(non Bt.) control plot. The treatments were applied at fortnightly intervals stating from $2^{\text {nd }}$ week of June. The jassid population was found infesting cotton crop. The data showed that the maximum population ( $2.38 \mathrm{jassid} / \mathrm{leaf})$ was recorded in $\mathrm{T} 4$, whereas minimum jassid population (1.76jassid/leaf) was recorded in T2. Over all maximum mean population of $C$. carnea $(0.39$ plant $)$ was recorded in T1 and the minimum population was recorded $(0.06 /$ plant $)$ in T2. The maximum seasonal mean of bolls (20.84bolls/plant) was recorded in T4 followed by T2 (20.13bolls/plant).
\end{abstract}

DOI: $10.7176 /$ ALST/77-03

Publication date: January $31^{\text {st }} 2020$

\section{INTRODUCTION}

Cotton Gossypium hirsutum L., is one of the most important fiber and cash crops of Pakistan, On a whole, Cotton is a major crop in parts of African tropics, Australia, China, Egypt, India, Mexico, Pakistan, Sudan, United States and warmer regions of central and South America (Bhatti and Soomro, 1996). Cotton was cultivated by the inhabitants of the Indus Valley civilization by the $5^{\text {th }}$ millennium BCE $-4^{\text {th }}$ millennium BCE. (Moseley and Gray, 2008).

White Gold contributes to the income of every tenth household in the country. More than two thirds of cotton producers own someone all of their land, whereas one fifth are shared croppers with no field of their own. Earnings from cotton sales accounts for 40 per cent and 45 percent of the household income of landowners and sharecroppers, respectively. As a result, among cotton farmers, 40 per cent of landowners and two thirds of sharecroppers are in the lowest two fifths of the consumption distribution. Households depending on sharecropping and selling labour for their livelihood include about one fifth of the rural population and have the highest incidence of poverty. Small and marginal farmers also face risks due to the high incidence of pest infestation and the equally high financial and health hazards resulting from the use and overuse of pesticides for plant protection. About eighty percent of all pesticides consumed in Pakistan are used on cotton fields (Siegmann, 2005).

Different approaches are applied by the farmers to control the insect pests including the cultivation of $\mathrm{Bt}$ cotton. Bt cotton was among the first genetically modified (GM) crops to be used in commercial agriculture. A gene from the soil bacterium Bacillus thuringiensis $(\mathrm{Bt})$ was transferred to the cotton genome. This gene encodes the production of a protein that is toxic to certain lepidopteran insects. Cotton is attacked by a variety of insect species, and the crop is the single largest insecticide consumer worldwide (Matthews and Tunstall, 1994) In the USA and China, Bt cotton was commercialized in the mid 1990s, and today the technology covers about 30-40 per cent of the cotton area in both countries. Recent studies show that USA and Chinese Bt adopters realize significant pesticide and cost savings in most cotton-producing regions (Carpenter et al. 2002) transgenic plants have shown good results against targeted insect pests, but they are infested by the other insect pests.

The green lacewing, C. carnea (Steph) is a potential predatory biological control agent that can be used in augmentation programs for sustainable crop pest suppression. It attacks a variety of soft-bodied insects and mites found on various agro-ecosystems. This predator is widely distributed in India, Europe, USSR, North America, South America, Tanzania, Sudan, Egypt, Kenya and Nigeria. The predator has a significant potential for commercialization and use against a variety of pests in combination with other insect pest management tactics (cultural, mechanical, host plant resistance, chemical and microbial insecticides). The predatory potential of the predator varies depending on the prey species (Gautam and Tesfaye 2002). In present study green lacewing, $C$. carnea is used as biological control agent against the jassid in Bt cotton.

\section{Objectives}

1. Comparative population development of Jassid pests on NIAB-78 and Bt cotton.

2. Evaluation of efficiency of Chrysoperla carnea (STEPH.) in population reduction of Jassid in Bt cotton. 


\section{MATERIALS AND METHODS}

The study was carried out to evaluate Chrysoperla cornea for the management of Jassid in Bt-Cotton crop, at Sindh Agriculture University, Tando Jam.

The study started from the $2^{\text {nd }}$ week of June and continued up to the last week of September. The process of recording data continued up to 16 week, up to that 20 observations were recorded, the experiment was carried out in four treatments with four replications in a $1 / 2$ acre. Each treatment plot size was $5445 \mathrm{sq} \mathrm{ft}$.

\section{LAYOUT OF THE PLOT}

\begin{tabular}{|c|c|c|c|c|c|}
\hline $\mathrm{T}_{1}$ & $=$ & Biology control, $(C)$ & erla & & \\
\hline $\mathrm{T}_{2}$ & $=$ & Confidor (Insecticid & & & \\
\hline $\mathrm{T}_{3}$ & $=$ & $\mathrm{Bt}-$ Control & & & \\
\hline \multirow[t]{5}{*}{$\mathrm{T}_{4}$} & $=$ & $\begin{array}{c}\text { NIAB- } 78 \text { Control } \\
\mathbf{R}_{\mathbf{1}}\end{array}$ & $\mathbf{R}_{2}$ & $\mathbf{R}_{3}$ & $\mathbf{R}_{4}$ \\
\hline & & $\mathrm{T}_{1}$ & $\mathrm{~T}_{3}$ & $\mathrm{~T}_{4}$ & $\mathrm{~T}_{2}$ \\
\hline & & $\mathrm{T}_{4}$ & $\mathrm{~T}_{2}$ & $\mathrm{~T}_{1}$ & $\mathrm{~T}_{3}$ \\
\hline & & $\mathrm{T}_{2}$ & $\mathrm{~T}_{1}$ & $\mathrm{~T}_{3}$ & $\mathrm{~T}_{4}$ \\
\hline & & $\mathrm{T}_{3}$ & $\mathrm{~T} 4$ & $\mathrm{~T}_{2}$ & $\mathrm{~T}_{1}$ \\
\hline
\end{tabular}

Comparative population development of Jassid, Amrasca devastans, were recorded in NIAB-78 and Bt cotton. The Chrysoperla carnea cards were purchased from Biological control laboratory, Nuclear Institute of Agriculture (NIA) Tandojam and Entomology section, Agriculture Research Institute, Tandojam. The predators were released in the field at fortnight interval.

Efficiency of $C$. carnea was compared with Confidor, one of the most popular insecticides widely used for the control of sucking insect pests by the farmers. The treatments were applied at fortnightly interval. Pretreatment data were recorded 24 hours before application and post treatment data were taken after three and seven days of application of treatments. The data were recorded by selecting five plants at random from each treatment. From each plant five leaves were observed for recording the population of sucking insects i.e., one from top, 2 from middle and 2 from bottom portion of plant and whole plant was observed for recording predator population. Crop yield parameters were also recorded. Finally collected data were analyzed using ANOVA.

\section{RESULTS}

Jassids, Amrasca devastans (Dist.)

Jassids population started its appearance on cotton crop in the $2^{\text {nd }}$ week of June and continued till the last week of September. When the temperature started to increase the pest population also increased. The maximum Jassid population $\left(6.23\right.$ / leaf) was recorded in T3 (B.T control plot) in the ${ }^{3 r d}$ week of June, while the minimum pest population (0.03/leaf) was recorded in the last week of August in T1 (in which natural enemies Chrysoperla cards) were released to suppress the pest population through biological control (Table-1).During the first week of August rainfall started which intermittently continued for many days and reduced the pest population. The over all, minimum Jassid population (1.67/leaf) was recorded in T2 (Confidor insecticide) plot, whereas the maximum pest population (2.38/leaf) was found in T4 (NIAB-78 control) plot (Table- 7). The analysis of data showed that there was a significant $(\mathrm{P}<0.05)$ in population of jassid on different treatments.

Table-1: Mean Population of Jassid, Amrasca devastans (Dist.) in different treatments on cotton crop under field conditions

\begin{tabular}{|c|c|c|c|c|c|}
\hline \multicolumn{7}{|c|}{ Mean population of jassid/leaf } \\
\hline Observation Date & T1 & T2 & T3 & T4 & Mean \\
\hline 15.06 .16 & 5.65 & 3.66 & 2.96 & 6.13 & $4.60 \mathrm{~B}$ \\
\hline 19.06 .16 & 5.19 & 2.34 & 6.23 & 5.43 & $4.80 \mathrm{~A}$ \\
\hline 23.06 .16 & 2.91 & 2.42 & 2.98 & 1.99 & $2.58 \mathrm{E}$ \\
\hline 30.06 .16 & 4.51 & 2.78 & 3.59 & 5.49 & $4.10 \mathrm{C}$ \\
\hline 04.07 .16 & 4.85 & 2.01 & 5.21 & 4.67 & $4.19 \mathrm{BC}$ \\
\hline 08.07 .16 & 3.46 & 3.85 & 3.77 & 4.07 & $3.79 \mathrm{CD}$ \\
\hline 15.07 .16 & 2.43 & 3.90 & 4.30 & 11.2 & $3.36 \mathrm{D}$ \\
\hline 19.07 .16 & 5.21 & 1.62 & 4.41 & 5.14 & $4.10 \mathrm{C}$ \\
\hline 23.07 .16 & 2.56 & 4.46 & 4.25 & 5.46 & $4.18 \mathrm{BC}$ \\
\hline 31.07 .16 & 1.34 & 0.30 & 2.24 & 2.06 & $2.23 \mathrm{E}$ \\
\hline 10.08 .16 & 0.71 & 0.64 & 0.90 & 0.36 & $0.65 \mathrm{~F}$ \\
\hline 14.08 .16 & 0.66 & 0.53 & 0.47 & 0.34 & $0.50 \mathrm{FG}$ \\
\hline 18.08 .16 & 0.73 & 0.53 & 0.72 & 0.40 & $0.60 \mathrm{FG}$ \\
\hline
\end{tabular}




\begin{tabular}{|c|c|c|c|c|c|}
\hline \multicolumn{7}{|c|}{ Mean population of jassid/leaf } & Mean \\
\hline Observation Date & T1 & T2 & T3 & 0.32 & $0.54 \mathrm{FG}$ \\
\hline 25.08 .16 & 0.73 & 0.54 & 0.56 & 0.29 & $0.21 \mathrm{G}$ \\
\hline 29.08 .16 & 0.03 & 0.19 & 0.34 & 0.31 & $0.36 \mathrm{FG}$ \\
\hline 02.09 .16 & 0.37 & 0.35 & 0.40 & 0.87 & $0.76 \mathrm{~F}$ \\
\hline 09.09 .16 & 0.82 & 0.78 & 0.55 & 0.97 & $0.60 \mathrm{FG}$ \\
\hline 13.09 .16 & 0.58 & 0.35 & 0.49 & 0.25 & $0.43 \mathrm{FG}$ \\
\hline 17.09 .16 & 0.51 & 0.52 & 0.44 & 0.31 & $0.48 \mathrm{FG}$ \\
\hline 24.09 .16 & 0.49 & 0.51 & 0.59 & 2.38 & 2.15 \\
\hline Mean & 2.19 & 1.76 & 2.27 & frem \\
\hline
\end{tabular}

* Means followed by same letters are not significantly $(\mathrm{P}<0.05)$ different

from each other by LSD.

Table-2 Mean Population of Jassid, Amrasca devastans (Dist.) after application of different IPM options on cotton crop under field conditions.

\begin{tabular}{|c|c|c|c|c|c|c|c|c|c|c|c|c|}
\hline \multirow{3}{*}{ Application } & \multicolumn{12}{|c|}{ Mean population of jassid/leaf } \\
\hline & \multicolumn{4}{|c|}{ Pre Treatment } & \multicolumn{4}{|c|}{ Post Treatment 3D } & \multicolumn{4}{|c|}{ Post Treatment 7D } \\
\hline & T1 & T2 & T3 & T4 & T1 & T2 & T3 & T4 & T1 & T2 & T3 & T4 \\
\hline 1 & 5.65 & 3.66 & 2.96 & 6.13 & 5.19 & 2.34 & 6.23 & 5.43 & 2.91 & 2.42 & 2.98 & 1.99 \\
\hline 2 & 4.51 & 2.78 & 3.59 & 5.49 & 4.85 & 2.01 & 5.21 & 4.67 & 3.46 & 3.85 & 3.77 & 4.07 \\
\hline 3 & 2.43 & 3.90 & 4.30 & 11.2 & 5.21 & 1.62 & 4.41 & 5.14 & 2.56 & 4.46 & 4.25 & 5.46 \\
\hline 4 & 0.71 & 0.64 & 0.90 & 0.36 & 0.66 & 0.53 & 0.47 & 0.34 & 0.73 & 0.53 & 0.72 & 0.40 \\
\hline 5 & 0.73 & 0.54 & 0.56 & 0.32 & 0.03 & 0.19 & 0.34 & 0.29 & 0.37 & 0.35 & 0.40 & 0.31 \\
\hline 6 & 0.82 & 0.78 & 0.55 & 0.87 & 0.58 & 0.35 & 0.49 & 0.97 & 0.51 & 0.52 & 0.44 & 0.25 \\
\hline Mean & 2.47 & 2.05 & 2.14 & 4.06 & 1.17 & 1.23 & 2.85 & 2.80 & 1.85 & 2.02 & 2.09 & 2.08 \\
\hline
\end{tabular}

Table-3 Overall mean population of pests in different treatments on cotton crop under field conditions.

\begin{tabular}{|c|c|}
\hline Treatment & Jassid Per Leaf \\
\hline $\mathrm{T} 1$ & $2.19 \mathrm{~B}$ \\
\hline $\mathrm{T} 2$ & $1.76 \mathrm{C}$ \\
\hline $\mathrm{T} 3$ & $2.27 \mathrm{AB}$ \\
\hline $\mathrm{T} 4$ & $2.38 \mathrm{~A}$ \\
\hline
\end{tabular}

* Means followed by same letters are not significantly $(\mathrm{P}<0.05)$ different from each other by LSD.

\section{IV.Green lacewing, Chrysoperla carnea (Steph.)}

Green lacewing Chrysoperla carnea (Steph.) is an important predator of aphid, whitefly, thrips and jassid. It is also called aphid lion. The $C$. carnea was recorded from the $2^{\text {nd }}$ week of June till the last week of September when the $1^{\text {st }}$ picking was taken, their maximum activities were recoded during $1^{\text {st }}$ week of August. The maximum population $(0.85 /$ plant $)$ was recorded in $\mathrm{T} 1$ in which natural enemies $(C$. carnea cards) were released as a pest management option (Table-8) the minimum population $(0.05 /$ plant) was recorded in the various treatments $\mathrm{T} 2, \mathrm{~T} 3$ and T4 (Confidor treatment), (B.T. control) and (NIAB-78) plots respectively. The over all mean population of $C$. carnea shown in (Table-10) indicated that the maximum $C$. carnea population was recorded (0.34/plant) in T1 $(C$. carnea natural enemies) plot, whereas the minimum population was recorded as (0.06/plant) in T2 (Confidor insecticide) plot. The analysis of data showed that there was a significant $(\mathrm{P}<0.05)$ difference in population development of $C$. carnea on different treatments. 
Table-4 Mean Population of green lacewing, Chrysoperla carnea (Steph.) in different treatments on cotton crop under field conditions.

\begin{tabular}{|c|c|c|c|c|c|}
\hline \multicolumn{7}{|c|}{ Mean population of green lacewing/plant } \\
\hline Observation Date & T1 & T2 & T3 & T4 & Mean \\
\hline 15.06 .16 & 0.30 & 0.25 & 0.20 & 0.15 & $0.23 \mathrm{ABC}$ \\
\hline 19.06 .16 & 0.55 & 0.05 & 0.10 & 0.25 & $0.24 \mathrm{ABC}$ \\
\hline 23.06 .16 & 0.40 & 0.10 & 0.20 & 0.10 & $0.19 \mathrm{BCDE}$ \\
\hline 30.06 .16 & 0.55 & 0.10 & 0.25 & 0.20 & $0.28 \mathrm{AB}$ \\
\hline 04.07 .16 & 0.85 & 0.05 & 0.15 & 0.15 & $0.30 \mathrm{~A}$ \\
\hline 08.07 .16 & 0.50 & 0.10 & 0.20 & 0.20 & O.25ABC \\
\hline 15.07 .16 & 0.35 & 0.10 & 0.10 & 0.15 & $0.17 \mathrm{CDEF}$ \\
\hline 19.07 .16 & 0.55 & 0.05 & 0.15 & 0.20 & $0.24 \mathrm{ABC}$ \\
\hline 23.07 .16 & 0.45 & 0.05 & 0.10 & 0.15 & $0.18 \mathrm{BCDE}$ \\
\hline 31.07 .16 & 0.35 & 0.05 & 0.10 & 0.15 & $0.16 \mathrm{CDEF}$ \\
\hline 10.08 .16 & 0.30 & 0.10 & 0.15 & 0.05 & $0.15 \mathrm{CDEF}$ \\
\hline 14.08 .16 & 0.40 & 0.05 & 0.15 & 0.25 & $0.21 \mathrm{ABC}$ \\
\hline 18.08 .16 & 0.35 & 0.05 & 0.15 & 0.20 & $0.17 \mathrm{CDEF}$ \\
\hline 25.08 .16 & 0.35 & 0.00 & 0.20 & 0.25 & $0.20 \mathrm{BCD}$ \\
\hline 29.08 .16 & 0.55 & 0.00 & 0.20 & 0.20 & $0.23 \mathrm{ABC}$ \\
\hline 02.09 .16 & 0.15 & 0.00 & 0.05 & 0.05 & $0.06 \mathrm{G}$ \\
\hline 09.09 .16 & 0.15 & 0.05 & 0.10 & 0.05 & $0.09 \mathrm{FG}$ \\
\hline 13.09 .16 & 0.35 & 0.05 & 0.05 & 0.00 & $0.11 \mathrm{DEFG}$ \\
\hline 17.09 .16 & 0.25 & 0.00 & 0.00 & 0.05 & $0.09 \mathrm{FG}$ \\
\hline 24.09 .16 & 0.30 & 0.05 & 0.00 & 0.05 & $0.10 \mathrm{EFG}$ \\
\hline Mean & 0.39 & 0.06 & 0.13 & 0.14 & 0.18 \\
\hline
\end{tabular}

* Means followed by same letters are not significantly $(\mathrm{P}<0.05)$ different from each other by LSD.

Table-5 Mean Population of green lacewing, Chrysoperla carnea (Steph.) after release of predator on cotton crop under field conditions.

\begin{tabular}{|c|c|c|c|c|c|c|c|c|c|c|c|c|}
\hline \multirow{3}{*}{ Application } & \multicolumn{10}{|c|}{ Mean population of green lacewing/plant } \\
\cline { 2 - 14 } & \multicolumn{4}{|c|}{ Pre Treatment } & \multicolumn{3}{c|}{ Post Treatment 3D } & \multicolumn{3}{c|}{ Post Treatment 7D } \\
\cline { 2 - 14 } & T1 & T2 & T3 & T4 & T1 & T2 & T3 & T4 & T1 & T2 & T3 & T4 \\
\hline 01 & 0.30 & 0.25 & 0.20 & 0.15 & 0.55 & 0.05 & 0.10 & 0.25 & 0.40 & 0.10 & 0.20 & 0.10 \\
\hline 02 & 0.55 & 0.10 & 0.25 & 0.20 & 0.85 & 0.05 & 0.15 & 0.15 & 0.50 & 0.10 & 0.20 & 0.20 \\
\hline 03 & 0.45 & 0.10 & 0.10 & 0.15 & 0.45 & 0.05 & 0.15 & 0.20 & 0.45 & 0.05 & 0.10 & 0.15 \\
\hline 04 & 0.30 & 0.01 & 0.15 & 0.20 & 0.40 & 0.05 & 0.15 & 0.15 & 0.35 & 0.05 & 0.15 & 0.20 \\
\hline 05 & 0.35 & 0.00 & 0.20 & 0.25 & 0.55 & 0.00 & 0.20 & 0.20 & 0.15 & 0.00 & 0.05 & 0.05 \\
\hline 06 & 0.15 & 0.05 & 0.10 & 0.05 & 0.35 & 0.05 & 0.00 & 0.05 & 0.25 & 0.00 & 0.00 & 0.05 \\
\hline Mean & 0.35 & 0.10 & 0.16 & 0.16 & 0.52 & 0.04 & 0.12 & 0.16 & 0.35 & 0.05 & 0.11 & 0.12 \\
\hline
\end{tabular}

Table-6 Overall mean population of green lacewing, Chrysoperla carnea (Steph.) in different treatments on Cotton crop under field conditions.

\begin{tabular}{|c|c|}
\hline \multicolumn{2}{|c|}{ Per Plant } \\
\hline Treatments & C. Carnea \\
\hline T1 & $0.39 \mathrm{~A}$ \\
\hline T2 & $0.06 \mathrm{C}$ \\
\hline T3 & $0.13 \mathrm{~B}$ \\
\hline T4 & $0.14 \mathrm{~B}$ \\
\hline
\end{tabular}

\footnotetext{
* Means followed by same letters are not significantly $(\mathrm{P}<0.05)$ different from each other by LSD.
}

\section{Cotton crop yield parameters}

\section{Height}

The Cotton plant attended maximum height of $(130.9 \mathrm{c} . \mathrm{m} / \mathrm{plant})$ recorded in T4 (NIAB-78 control) plot in the $2^{\text {nd }}$ fortnight of September (Table-11) the minimum height $(74.40 \mathrm{c} . \mathrm{m} / \mathrm{plant})$ in T3 (B.T. control) plot in the $2^{\text {nd }}$ fortnight of July. The overall mean maximum height was recorded $(111.10 \mathrm{c} . \mathrm{m} / \mathrm{plant})$ in T4 (NIAB-78 control) plot; where as the minimum height $(84.33 \mathrm{c} . \mathrm{m} /$ plant) was recorded in (B.T. control) plot, as shown in (Table- 7). 


\section{Bolls}

The maximum number of bolls (25.9/plant) was recorded in T4 (NAB-78 control plot) during the $2^{\text {nd }}$ fortnight of August, where as the minimum number of bolls (0.8/plant) was recorded in T3 (B.T. control) plot during the $2^{\text {nd }}$ fortnight of September (Table-11). The overall maximum number of bolls (20.84/plant) was recorded in T4 (NAB78 control plot) whereas the minimum number of bolls was recorded (13.36/plant) in T3 (B.T. control) plot (Table7). The analysis of data showed that there was a significant $(\mathrm{P}<0.05)$ difference in formation of bolls in different treatments.

Table-7 Cotton yield parameters (per plant) in different treatments under field condition.

\begin{tabular}{|c|c|c|c|}
\hline Fortnight & Treatments & Plant Height & No. of Bolls \\
\hline \multirow[t]{4}{*}{$2^{\text {nd }}$ July } & $\mathrm{T} 1$ & 71.60 & 09.55 \\
\hline & $\mathrm{T} 2$ & 99.10 & 16.50 \\
\hline & $\mathrm{T} 3$ & 73.40 & 12.25 \\
\hline & $\mathrm{T} 4$ & 96.50 & 13.55 \\
\hline \multirow[t]{4}{*}{$1^{\text {st }}$ August } & $\mathrm{T} 1$ & 104.8 & 14.50 \\
\hline & $\mathrm{T} 2$ & 103.6 & 13.65 \\
\hline & T3 & 93.90 & 08.85 \\
\hline & T4 & 108.8 & 21.45 \\
\hline \multirow[t]{4}{*}{$2^{\text {nd }}$ August } & T1 & 107.9 & 20.65 \\
\hline & $\mathrm{T} 2$ & 102.9 & 24.40 \\
\hline & T3 & 92.90 & 15.95 \\
\hline & $\mathrm{T} 4$ & 110.0 & 19.40 \\
\hline \multirow[t]{4}{*}{$1^{\text {st }}$ September } & $\mathrm{T} 1$ & 111.6 & 20.00 \\
\hline & $\mathrm{T} 2$ & 107.9 & 19.70 \\
\hline & T3 & 83.80 & 18.15 \\
\hline & $\mathrm{T} 4$ & 109.0 & 23.90 \\
\hline \multirow[t]{4}{*}{$2^{\text {nd }}$ September } & T1 & 106.3 & 22.30 \\
\hline & $\mathrm{T} 2$ & 101.2 & 26.40 \\
\hline & T3 & 78.20 & 11.60 \\
\hline & T4 & 130.9 & 25.90 \\
\hline
\end{tabular}

Table-8 Overall mean (per plant) of cotton yield parameters in different treatments under field conditions.

\begin{tabular}{|l|l|l|}
\hline \multicolumn{1}{|c|}{ Treatments } & \multicolumn{1}{|c|}{ Plant Height } & \multicolumn{1}{c|}{ No. of Bolls } \\
\hline T1 & $100.4 \mathrm{~B}$ & $17.40 \mathrm{~B}$ \\
\hline T2 & $102.9 \mathrm{~B}$ & $20.13 \mathrm{~A}$ \\
\hline T3 & $84.33 \mathrm{C}$ & $13.36 \mathrm{C}$ \\
\hline T4 & $111.10 \mathrm{~A}$ & $20.84 \mathrm{~A}$ \\
\hline
\end{tabular}

* Means followed by same letters are not significantly $(\mathrm{P}<0.05)$ different from each other by LSD.

\section{DISCUSSION}

In present study different pest management options were tested on Bt- cotton against sucking insect pests. Release of $C$. carnea cards in cotton reduced the population of jassid, thrips and white fly compared with control. Jassid population was slightly lower in Bt Cotton control compared with NIAB-78 control. Similarly whitefly population was lower in Bt-cotton control compared to NIAB-78 control. Hanumantharaya and Naik (2008) studied the release of Chrysoperla carnea grubs at 0.75 and 1.0 lakhs/ha. Starting from 43 DAS reduced the sucking pest (leaf hoppers, thrips, aphids and whiteflies) and bollworm $H$. armigera and increased the seed cotton yield. Wadhawa and Gill (2007) studied the biodiversity of natural enemies on $\mathrm{Bt}$ and non-Bt cotton hybrids and found that $\mathrm{Bt}$ cotton hybrid recorded higher population of Chrysoperla carnea, spiders, Geocoris bug, and yellow wasps. Manju et al. (2007) investigated the effect of Bt- cotton fed aphids on the feeding potential and development of $C$. carnea and reported no variation in the feeding potential and development period of larvae of $C$. carnea fed on aphids feeding on $\mathrm{Bt}$ and non $\mathrm{Bt}$ cotton plants. They recorded significantly higher number of natural enemies on $\mathrm{Bt}-$ Cotton compared with non Bt- cotton.

In present study, confidor was applied on Bt- cotton for the control of sucking insect pests, results indicated that confidor significantly reduced jassid population compared with $C$. carnea and control treatments. Confidor was not much effective against thrips and whitefly. Results further indicate that confidor was toxic to $C$. carnea and lowest population of $C$. carnea was recorded in confidor applied treatment. Ameta and Sharma (2005) recorded reduction in population of $A$. gossypii, A. biguttula and $T$. tabacci after application of confidor. Chaudhary et al. (2005) also reported that confidor was superior than Clothianidia in controlling the jassid populations in cotton. 


\section{Conclusion}

Bt cotton is susceptible to thrips compared to NIAB - 78. Both the treatments (Chrysoperla carnea and Confidor) suppressed the insect pest's population. Confidor significantly reduced jassid population whereas it was not much effective against thrips and whitefly. The confidor was toxic to $C$. carnea (predator); lowest population was recorded in confidor treated plot.

\section{References}

Ameta O.P and Sharma K.C. 2005. Bioefficacy of imidacloprid (Confidor) against sucking insect pests of cotton. Insect Environment, 11:66-70.

Balasubramani V. and Swamiappan M. 1997. Persistent toxicity of some insecticides to the green lacewing Chrysoperla carnea (Chrysopidae:Neuroptera). Journal of Ecotoxicology \& Environmental Monitoring, 7:197-200.

Bhatti I.B. and Soomro A.H. 1996. Agriculture Inputs and Field Crop Production in Sindh. Published by Agriculture Research Sindh, Hyderabad 40-41pp.

Carpenter J., Felsot A., Goode T., Hammig M., Onstad D. and Zankula S. 2002. Comparative Environmental Impacts of Biotechnology- derived and Traditional Soybean, Corn, and Cotton Crops, Ames: Council for Agricultural Science and Technology.

Choudhary R.K., Tomar S.P.S., Shrivastava V.K., and Yadav A.S. 2005. Studies on field evaluation of imidacloprid Confidor 17.8 SL) against sucking pests of cotton in rainfed condition. Journal of Cotton Research and Development. 19:241-243.

El-Heneidy A.H. and Sekamatte B. 1996. Comparative population densities of certain predatory species in two cotton field ecosystems in Uganda. Annals of Agricultural Science, Moshtohor, 34:1189-1199.

Gerling, D. Kravchenko V.and Lazare M. 1997. Dynamics of common green lacewing (Neuroptera: Chrysopidae) in Israeli cotton fields in relation to whitefly (Homoptera: Aleyrodidae) populations. Environmental Entomology 26:815-827.

Hanumantharaya L. Goud K. B and. Naik L.K. 2008. Use of green lacewing, Chrysoperla carnea (Stephens) and neem seed kernel extract for management of insect pests on cotton. Karnataka Journal of Agricultural Sciences. 21: 41-44.

Manju A.C. Patil B.V.. Bheemanna M.. Hosamani A. C. Hanchinal S.G. and Bansi A.B. 2007. Influence of Bt cotton fed aphids on the feeding potential and development of Chrysoperla carnea (Stephens). Cotton Research and Development. 21:118-119.

Matthew G.A. and Tunstall J. P.(eds). 1994. Insect Pests of Cotton. Published by CAB International Wallingford U. K.

Moseley W. G. and Gray L.C.(eds). 2008. Hanging by a Thread: Cotton, Globalization and poverty in Africa. Athens OH: Ohio University Press and Nordic Africa Press. ISBN 978-0-89680- 260-5

Saminathan V. R. Mahadevan N. R and. Muthukrishnan N. 2003. Influence of prey density on the predatory potential and development ofChrysoperla carnea. Indian Journal of Entomology. 65:1-6.

Siegmann, K. A. 2005. Poverty despite productivity: Part I, The News Sunday $19^{\text {th }}$ June, Rawalpindi/Islamabad.

Wadhwa, S. and Gill R. S. 2007. Effect of Bt-cotton on biodiversity of natural enemies. Journal of Biological Control. 21:9-16. 